This item was submitted to Loughborough's Research Repository by the author.

Items in Figshare are protected by copyright, with all rights reserved, unless otherwise indicated.

\title{
Synthesis and activity of a novel Autotaxin inhibitor-Icodextrin conjugate
}

PLEASE CITE THE PUBLISHED VERSION

https://doi.org/10.1021/acs.jmedchem.8b00935

PUBLISHER

() American Chemical Society (ACS)

VERSION

AM (Accepted Manuscript)

\section{PUBLISHER STATEMENT}

This work is made available according to the conditions of the Creative Commons Attribution-NonCommercialNoDerivatives 4.0 International (CC BY-NC-ND 4.0) licence. Full details of this licence are available at: https://creativecommons.org/licenses/by-nc-nd/4.0/

\section{LICENCE}

CC BY-NC-ND 4.0

\section{REPOSITORY RECORD}

Fisher, Natalie, Michael G. Edwards, Ryan Hemming, Steven M. Allin, John D. Wallis, Philip C. Bulman Page, Michael J. McKenzie, et al.. 2019. "Synthesis and Activity of a Novel Autotaxin Inhibitor-icodextrin Conjugate". figshare. https://hdl.handle.net/2134/35246. 


\section{Synthesis and Activity of a Novel Autotaxin Inhibitor-Icodextrin Conjugate}

Natalie Fisher, ${ }^{\text {a,b }}$ Michael G. Edwards, ${ }^{b}$ Ryan Hemming, ${ }^{c}$ Steven M. Allin, ${ }^{c}$ John D. Wallis,

Philip C. Bulman Page, ${ }^{\mathrm{d}}$ Michael J. Mckenzie, ${ }^{\mathrm{e}}$ Stefanie M Jones, ${ }^{\mathrm{a}}$ Mark R. J. Elsegood, ${ }^{\mathrm{f}}$ John King-Underwood ${ }^{\mathrm{g}}$ and Alan Richardson ${ }^{\mathrm{a} *}$

a School of Pharmacy, Keele University, Keele, ST5 5BG, UK

${ }^{\mathrm{b}}$ Keele Molecular Chemistry Group, Lennard-Jones Laboratories, School of Chemical and Physical Sciences, Keele University, Keele, ST5 5BG, UK

${ }^{c}$ School of Science and Technology, Nottingham Trent University, Nottingham NG11 8NS, UK

${ }^{\mathrm{d}}$ School of Chemistry, University of East Anglia, Norwich NR4 7TJ

${ }^{\text {e }}$ Charnwood Molecular Ltd., The Heritage Building, Prince William Road, Loughborough LE11 5DA, UK

${ }^{\mathrm{f}}$ Department of Chemistry, Loughborough University, Loughborough, LE11 3TU, UK

${ }^{g}$ Computational Chemistry Resource, Old Cottage Hospital, Ledbury, HR8 1ED, UK 


\section{ORCHID}

Alan Richardson 0000-0003-1825-3375

*Corresponding author: a.richardson1@keele.ac.uk 


\section{ABSTRACT}

Autotaxin is an extracellular phospholipase $\mathrm{D}$ that catalyses the hydrolysis of lysophosphatidyl choline (LPC) to generate the bioactive lipid lysophosphatidic acid (LPA). Autotaxin has been implicated in many pathological processes relevant to cancer. Intraperitoneal administration of an autotaxin inhibitor may benefit patients with ovarian cancer, however low molecular mass compounds are known to be rapidly cleared from the peritoneal cavity. Icodextrin is a polymer that is already in clinical use because it is slowly eliminated from the peritoneal cavity. Herein we report conjugation of the autotaxin inhibitor HA-155 to icodextrin. The conjugate inhibits autotaxin activity $\left(\mathrm{IC}_{50}=0.86 \pm 0.13 \mu \mathrm{g} \mathrm{mL}{ }^{-1}\right)$ and reduces cell migration. Conjugation of the inhibitor increased its solubility, decreased its membrane permeability and improved its intraperitoneal retention in mice. These observations demonstrate the first application of icodextrin as a covalently-bonded drug delivery platform with potential use in the treatment of ovarian cancer. 


\section{INTRODUCTION}

Autotaxin is an extracellular phospholipase $\mathrm{D}^{1}$ that hydrolyses lysophosphatidyl choline (LPC) to the bioactive lipid lysophosphatidic acid (LPA) and choline. ${ }^{2}$ LPA acts via G protein coupled receptors located on the cell surface to activate a variety of signaling pathways. $^{3}$ LPA-induced signaling pathways are implicated in a number of biological processes including cell migration, proliferation and survival. ${ }^{4}$ Patients with ovarian cancer often present with an accumulation of ascites fluid in the intraperitoneal cavity which contains LPA at concentrations up to $80 \mu \mathrm{M} .^{5}$ Autotaxin, also found in the ascites fluid of patients with ovarian cancer, ${ }^{6}$ is over-expressed in ovarian cancers that are resistant to chemotherapy, ${ }^{7}$ and has been shown to delay apoptosis induced by carboplatin in ovarian cancer cells. ${ }^{8}$ Autotaxin is known to catalyse the production of LPA in many biological fluids $^{2 \mathrm{~b}}$ and LPA has a well-established role in cancer cell migration and invasion. ${ }^{9}$

Inhibition of autotaxin has been shown to increase the sensitivity of ovarian cancer cells to carboplatin ${ }^{10}$ and breast cancer cells to paclitaxel. ${ }^{11}$ Reducing the high levels of LPA present in ascites could therefore be expected to delay relapse after chemotherapy and reduce drug resistance, suggesting that a strategy involving inhibition of autotaxin within the peritoneal cavity has therapeutic potential for the treatment of ovarian cancer. Several small molecule inhibitors of autotaxin have been described ${ }^{12}$ which might be used to achieve this. Maintaining a high local concentration of an autotaxin inhibitor within the peritoneal cavity is likely to be important in order to ensure sufficient and prolonged inhibition of this enzyme. ${ }^{13}$ However, the residence time of small molecule drugs within the peritoneal cavity is usually relatively short because low molecular mass compounds are quickly absorbed through the peritoneal capillaries into the systemic circulation. In contrast, high molecular mass compounds are generally cleared more slowly from the peritoneal cavity, suggesting that coupling of a drug to a polymer offers a potential strategy to increase the residence time of the therapeutic agent. 
Polymers are becoming an increasingly useful tool in the delivery of drugs and have the potential to improve the desired therapeutic properties of bioactive small molecules. We have previously described the successful synthesis and attachment of the known autotaxin inhibitor S32826 to a $3^{\text {rd }}$ generation PAMAM dendrimer whilst retaining pharmacological activity, demonstrating the feasibility of conjugating autotaxin inhibitors to a polymeric delivery system. ${ }^{14}$

In the related studies described in this paper, our attention was drawn to the potential application of icodextrin as an alternative polymeric support. Icodextrin is the main constituent of Extraneal ${ }^{\mathrm{TM}}$, which has a history of safe clinical use for peritoneal dialysis. Icodextrin is a water-soluble polymer derived from maltodextrin containing $\alpha$-1,4-glycosidic bonds and approximately $10 \% \alpha$-1,6-glycosidic bonds, and an average molecular weight of $13-19 \mathrm{kDa}$. The prolonged retention of icodextrin in the intraperitoneal cavity has been well characterized in clinical trials and is the basis for its clinical use in peritoneal dialysis, with approximately $60 \%$ of the icodextrin administered to the intraperitoneal cavity remaining after 12 hours. ${ }^{15}$ Higher molecular weight icodextrin fractions are anticipated to be eliminated even more slowly. There have been several studies which have evaluated the coadministration of non-covalently coupled icodextrin, as a carrier solution to increase the retention of drug molecules in the peritoneal cavity ${ }^{16}$ but to our knowledge there have been no reports detailing the use of icodextrin as a support to form a covalently-bound drug conjugate. Given the many advantages noted above, we reasoned that icodextrin could be investigated as a novel drug delivery system for intraperitoneal administration and targeting of the autotaxin-LPC system in the peritoneal cavity. Herein we describe our progress, and report the synthesis and activity of a novel autotaxin inhibitor-icodextrin conjugate based on the autotaxin inhibitor HA- $155 .^{17}$ 


\section{RESULTS AND DISCUSSION}

The publication ${ }^{18}$ of the crystal structure of autotaxin in complex with the small-molecule inhibitor HA155 enabled us to perform structure-based drug design of a drug-polymer conjugate. Inspection of the molecular structure suggested that the 3-position on the central benzylidene moiety was accessible to solvent and might provide an appropriate locus to cross-link the drug to a polymer without interfering with the drug binding to the enzyme (Fig 1). ${ }^{16}$ Furthermore, structurally related compounds described by Albers ${ }^{17}$ contained a methoxy group at this position, suggesting substitution was tolerated at this position. We chose to replace the boronic acid moiety in HA155 with a carboxylic acid because this was previously shown to be tolerated ${ }^{17}$ and because boronic acid is found in relatively few marketed drugs.

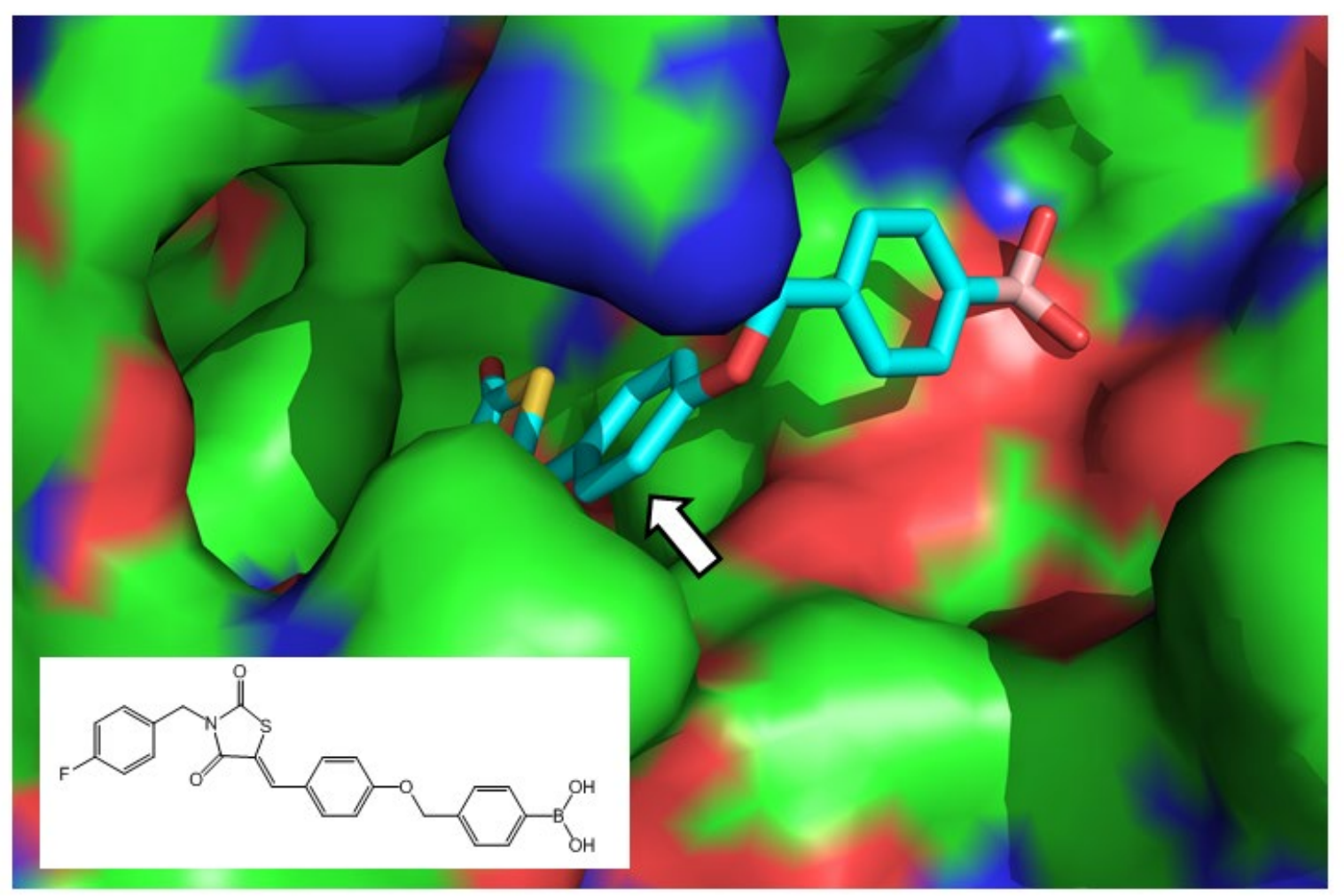

Figure 1. Crystal structure of HA155 bound to autotaxin (adapted from ref 18). The structure of HA155 is shown in the inset. The proposed attachment point for the polymer is shown (arrow). 
A convenient and convergent synthetic approach based on the modification of a route previously used to synthesise HA155 ${ }^{17}$ was pursued (Scheme 1). Thiazolidine-2,4-dione was $\mathrm{N}$-benzylated with 4-fluorobenzyl chloride to yield intermediate 1. Selective $O$-benzylation of 3,4-dihydroxybenzaldehyde with methyl-4-(bromomethyl)-benzoate following a method described by Plourde and Spaetzel ${ }^{19}$ using Finkelstein conditions $\left(\mathrm{NaHCO}_{3}, \mathrm{NaI}, \mathrm{DMF}, 40\right.$ ${ }^{\circ} \mathrm{C}$ ) allowed benzylation of the C4-hydroxyl group; the structure of compound 2 was confirmed by single crystal X-Ray diffraction (Figure 2).

Our initial studies evaluated the direct attachment of $\mathbf{2}$ to the polymer via the remaining C3phenolic hydroxyl group, however inconsistent coupling at this stage prompted us to incorporate a spacer group in the form of a bis-ethylene glycol linker. This was accomplished by alkylation of the C3-hydroxyl group in $\mathbf{2}$ with 2-(2-chloroethoxy)-ethanol. Saponification of the resulting methyl ester with sodium hydroxide gave intermediate 3. Finally, a Knoevenagel-like condensation of the thiazolane-2,4-dione 1 with aldehyde 3 delivered the novel, functionalized autotaxin inhibitor, 4. 


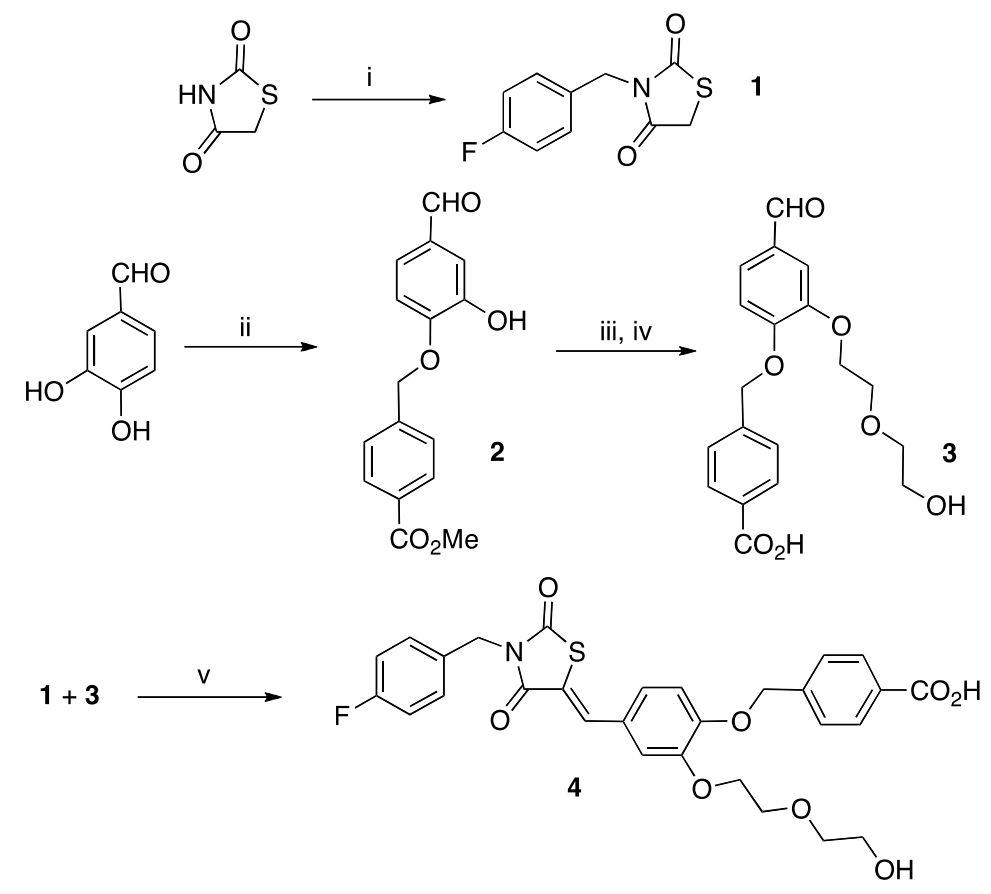

Scheme 1. Synthesis of functionalized autotaxin inhibitor, 4: i. NaH, DMF, $0{ }^{\circ} \mathrm{C}$ to $\mathrm{rt}, 22 \mathrm{~h}(75 \%)$; ii. $\mathrm{NaHCO}_{3}$, NaI, DMF, $40{ }^{\circ} \mathrm{C}, 24 \mathrm{~h}(70 \%)$; iii. 2-(2-chloroethoxy)-ethanol, DMF, $\mathrm{K}_{2} \mathrm{CO}_{3}, \mathrm{KI}, 70{ }^{\circ} \mathrm{C}, 18$ h (58\%); iv. $\mathrm{NaOH}, \mathrm{DMSO} / \mathrm{H}_{2} \mathrm{O} 70{ }^{\circ} \mathrm{C}, 2 \mathrm{~h}$ (98\%); v. piperidine, EtOH, reflux, 16 h (93\%).

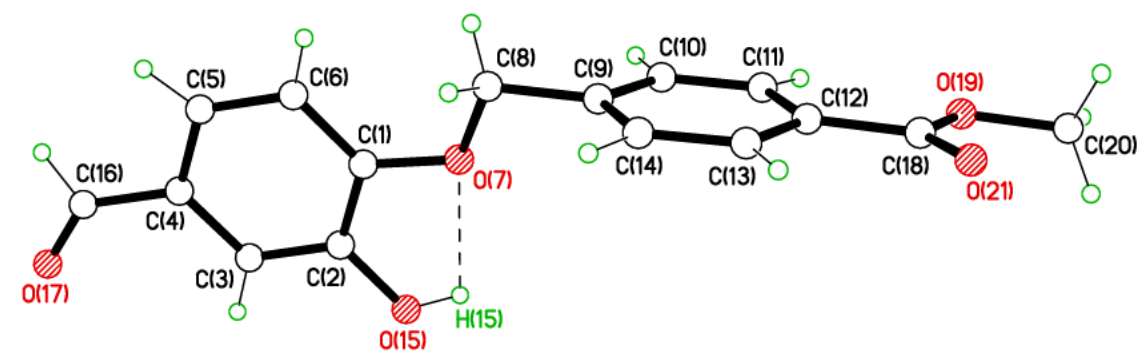

Figure 2: X-Ray structure of the selectively benzylated intermediate 2. Displacement ellipsoids are at the $50 \%$ probability level. Intramolecular H-bond shown with a dashed line.

In order to investigate its potential for supporting an appropriately derivatised autotaxin inhibitor molecule, icodextrin solid was isolated from Extraneal ${ }^{\mathrm{TM}}$ by dialysis against water to remove electrolytes, small organic molecule contaminants and icodextrin chains smaller than $20 \mathrm{kDa}^{20}$ 
To facilitate the attachment of the inhibitor derivative 4 to icodextrin it was necessary to introduce an appropriate electrophilic functional group, capable of allowing alkylation of the primary alcohol at the C6 position of the glucose units in icodextrin. Thus the carboxylic acid group in $\mathbf{4}$ was first protected as the TIPS silyl ester $\mathbf{5}$, before activation of the terminal hydroxyl group of the linker moiety within $\mathbf{5}$ as the tosylate $\mathbf{6}$. Icodextrin is poorly soluble in organic solvents due to extensive hydrogen bonding and incorporated water, but can be dissolved in $N, N$-dimethylacetamide (DMAc) with added $\mathrm{LiCl}$ to displace water. ${ }^{21}$ Once icodextrin had been dissolved in the DMAc/LiCl mixture, the coupling of icodextrin and 6 was achieved through deprotonation of icodextrin using sodium hydride, followed by addition of tosylate $\mathbf{6}$. The novel icodextrin-inhibitor conjugate 7 was finally isolated by dialysis of the reaction mixture against methanol. This synthetic procedure was found to lead to in situ removal of the TIPS ptotecting group from the conjugate. The structure of conjugate 7 was supported by NMR, IR and TGA analysis (Figure 3). An unconjugated analogue of 7 was also prepared (8) in order to allow comparisons to be drawn on the effect of the icodextrin coupling on the activity of the supported compound. Table 1 summarizes some chemical and pharmaceutical properties of conjugate 7 . 


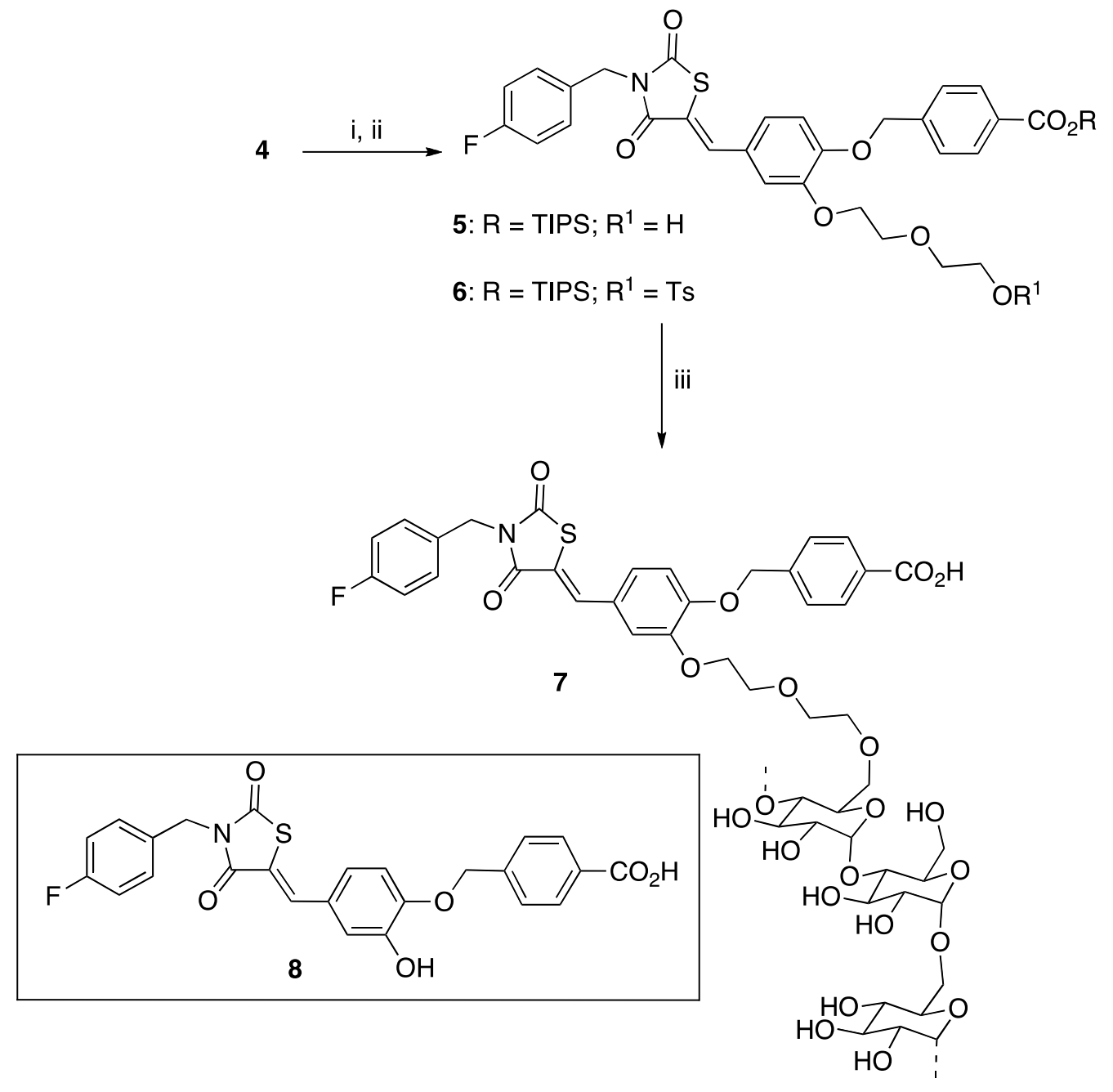

Scheme 2. Synthesis of icodextrin-inhibitor conjugate: $\mathrm{i}$. TIPS-Cl, Et $3 \mathrm{~N}, \mathrm{THF}, \mathrm{rt}, 15 \mathrm{~min}(76 \%)$; ii. $p$-TsCl, $\mathrm{CH}_{2} \mathrm{Cl}_{2}, \mathrm{Et}_{3} \mathrm{~N}, \mathrm{rt}, 20$ h (61\%); iii. Icodextrin, $\mathrm{NaH}, \mathrm{LiCl}, \mathrm{DMAc}, \mathrm{rt}, 4$ h (43\%). 


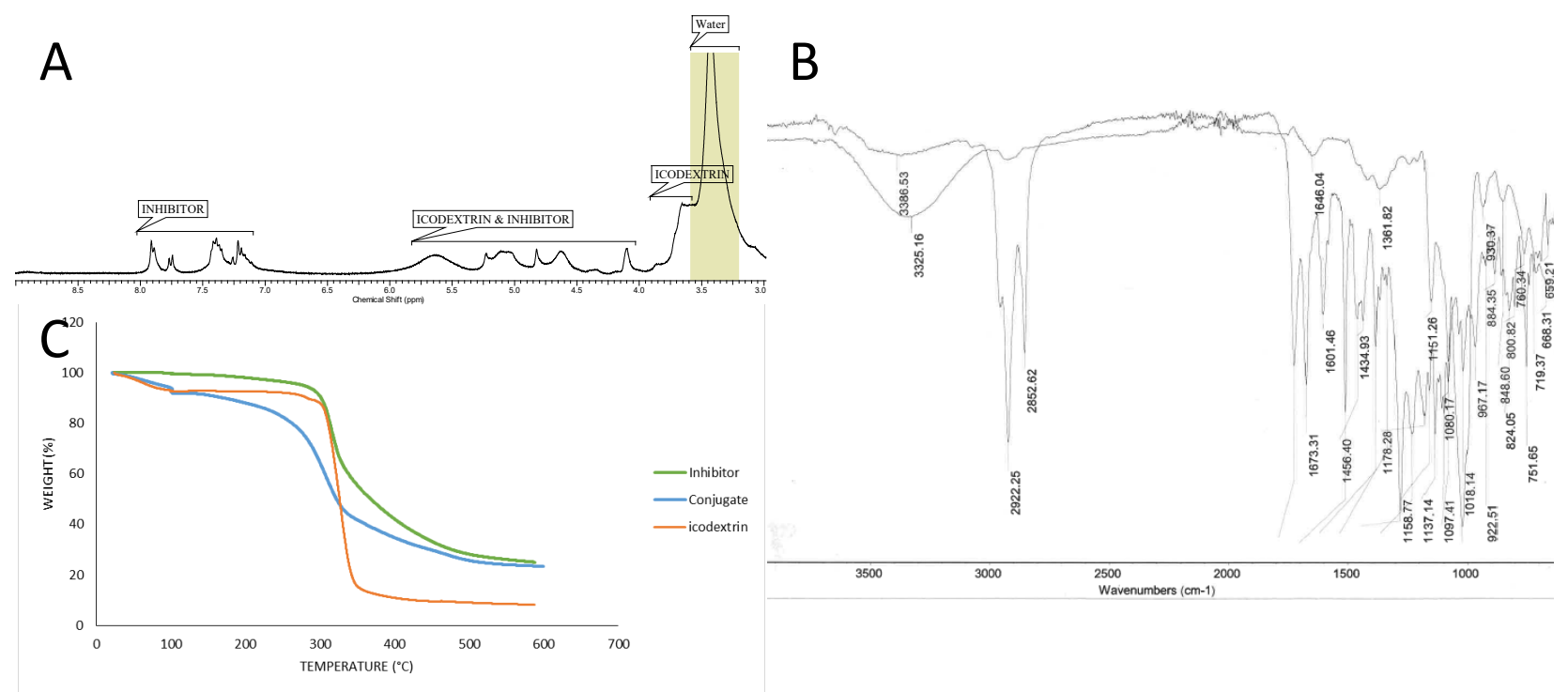

Figure 3: Analysis of icodextrin-inhibitor conjugate 7: A) $300 \mathrm{MHz}{ }^{1} \mathrm{H} \mathrm{NMR}$ analysis of conjugate 7; B) IR analysis of free inhibitor 8 and conjugate 7; C) TGA analysis of free inhibitor $\mathbf{8}$, icodextrin, and icodextrin-inhibitor conjugate 7.

To establish the amount of inhibitor attached to the conjugate, the inherent fluorescence of the immobilized inhibitor was measured in a solution of 7 and compared with the fluorescence of known concentrations of non-conjugated, free inhibitor 8. Knowing the concentration of dissolved polymer allowed us to determine that approximately $0.09 \mathrm{~g}$ of the inhibitor molecule was attached per $\mathrm{g}$ of polymer $\left(0.19 \mathrm{mmol} \mathrm{g}^{-1}\right)$.

The aqueous solubility of the compounds in PBS ( $\mathrm{pH} 7.4$ ) was tested using a miniaturized shake flask method, and conjugation to icodextrin was observed to increase the solubility of the pharmacophore compared with the free inhibitor 8 (Table 1).

It was hypothesized that conjugation to icodextrin would increase the retention time of the autotaxin inhibitor in the intraperitoneal cavity (due to the substantial increase in size slowing down its absorption). The effect of conjugation on the membrane permeability of the 
compounds was tested in two assays: (i) in a PAMPA assay measuring diffusion across an artificial bilayer and (ii) using a Caco-2 cell monolayer. In the PAMPA assay, the unconjugated inhibitor $\mathbf{8}$ was observed to be moderately permeable across the membrane but once the inhibitor was conjugated to icodextrin there was a marked decrease in permeability (i.e. of conjugate 7$)$. In the Caco-2 assay, conjugate 7 also showed poor permeability $\left(\mathrm{P}_{\mathrm{app}}=\right.$ $\left.7.4 \times 10^{-6}\right)$ when compared with a freely permeable drug, paracetamol $\left(\mathrm{P}_{\mathrm{app}}=38 \times 10^{-6}\right)$.

\begin{tabular}{|c|c|c|c|}
\hline Compound & $\begin{array}{l}\text { Degree of incorporation } \\
\text { of inhibitor } \\
\left(\mathrm{mmol} \mathrm{g}^{-1}\right)\end{array}$ & $\begin{array}{l}\text { Solubility } \\
\qquad\left(\mathrm{g} \mathrm{L}^{-1}\right)\end{array}$ & $\begin{array}{c}\text { Permeability } \\
\text { (Log Pe) }\end{array}$ \\
\hline Free inhibitor 8 & $\mathrm{n} / \mathrm{a}$ & $0.08 \pm 0.02$ & $-5.5 \pm 0.2$ \\
\hline Conjugate 7 & 0.19 & $0.22 \pm 0.02$ & $-6.4 \pm 0.1$ \\
\hline
\end{tabular}

Table 1: Chemical and Pharmaceutical Properties of Conjugate 7 and Free Inhibitor 8: Solubility was measured using a miniaturised shake flask method. (Results are expressed as mean \pm S.D. $n=3$ ); Permeability was measured in PAMPA assay. Permeability (mean +S.D., $\mathrm{n}=2-3)$ of the free inhibitor 8 and conjugate 7 were determined using furosemide $(\log P e=$ $-6.4 \pm 0.3)$ and propranolol $(\log \mathrm{Pe}=-5.3 \pm 0.1)$ as controls for low and high permeable drugs respectively. 


\section{AUTOTAXIN ACTIVITY ASSAYS}

The ability of the novel conjugate 7 to inhibit autotaxin was assessed in two autotaxin enzymatic activity assays measuring the hydrolysis of two different substrates, FS- $3^{22}$ and Bis $p$-NPP. ${ }^{22,}{ }^{23}$ Using FS-3 as the substrate, both conjugate 7 and the free inhibitor 8 inhibited the activity of autotaxin. When the potency of conjugate 7 was expressed in terms of the concentration of pharmacophore attached to the polymer, conjugation appeared have had minimal effect on the drug potency (Table 2). Using bis- $p$ NPP as the substrate, the free inhibitor $\mathbf{8}$ showed a slightly lower potency to that measured in the FS-3 assay (Table 2) but the potency of the conjugate 7 was comparable in both assays. Unconjugated icodextrin itself $\left(100 \mu \mathrm{g} \mathrm{mL}^{-1}\right)$ had no measureable effect in either assay.

\begin{tabular}{|c|c|c|}
\hline \multirow{2}{*}{ Compound } & \multicolumn{2}{|c|}{ IC50 } \\
\cline { 2 - 3 } & $290 \pm 160 \mathrm{nM}(\mathrm{n}=5)$ & Bis- $p$ NPP assay \\
\hline Free inhibitor 8 & $0.86 \pm 0.13 \mu \mathrm{g} \mathrm{mL}^{-1}(\mathrm{n}=4)$ & $620 \pm 160 \mathrm{nM}(\mathrm{n}=2)$ \\
\hline \multirow{2}{*}{ Conjugate 7 } & $\left\{\right.$ pharmacophore $\left.\mathrm{IC}_{50}=160 \pm 20 \mathrm{nM}\right\}$ & $\left\{\right.$ pharmacophore $\left.\mathrm{IC}_{50}=170 \pm 20 \mathrm{nM}\right\}$ \\
\hline
\end{tabular}

Table 2: Inhibition of autotaxin enzymatic activity by the free inhibitor $\mathbf{8}$ and conjugate $\mathbf{7}$, tested in FS-3 and Bis- $p$ NPP assay. $\mathrm{IC}_{50}$ values (mean \pm S.D., number (n) of experiments shown in parentheses)) are shown as either the concentration of conjugate $\left(\mu \mathrm{g} \mathrm{mL} \mathrm{m}^{-1}\right)$ or the concentration of the free inhibitor $(\mathrm{nM})$. To allow comparision, the $\mathrm{IC}_{50}$ of the conjugate is also expressed in terms of the concentration of the pharmacophore present, determined by taking into account the amount of drug conjugated to the icodextrin. 


\section{INHIBITION OF CELL MIGRATION}

Autotaxin and LPA have been shown to regulate the migration of cancer cells. To further invetigate the biological activity of conjugate 7, its effect on wound healing was evaluated using 3E3 ovarian cancer cells; these cells were previously derived from OVCAR-3 cells to over-express autotaxin. ${ }^{10}$ OVCAR-3 cells transfected with the vector $3 \mathrm{~V} 5$, were used as a control and express low levels of autotaxin. ${ }^{10}$ Once an even monolayer of cells had formed a wound was inflicted and the migration of the cells was measured. Both the free autotaxin inhibitor $\mathbf{8}$ and the icodextrin-drug conjugate 7 were observed to reduce wound closure by approximately 50\% compared with cells exposed to vehicle alone (DMSO), (Figure 4). Neither the free autotaxin inhibitor 8 nor the conjugate 7 had a significant effect on the percentage wound closure in the control 3V5 cells.
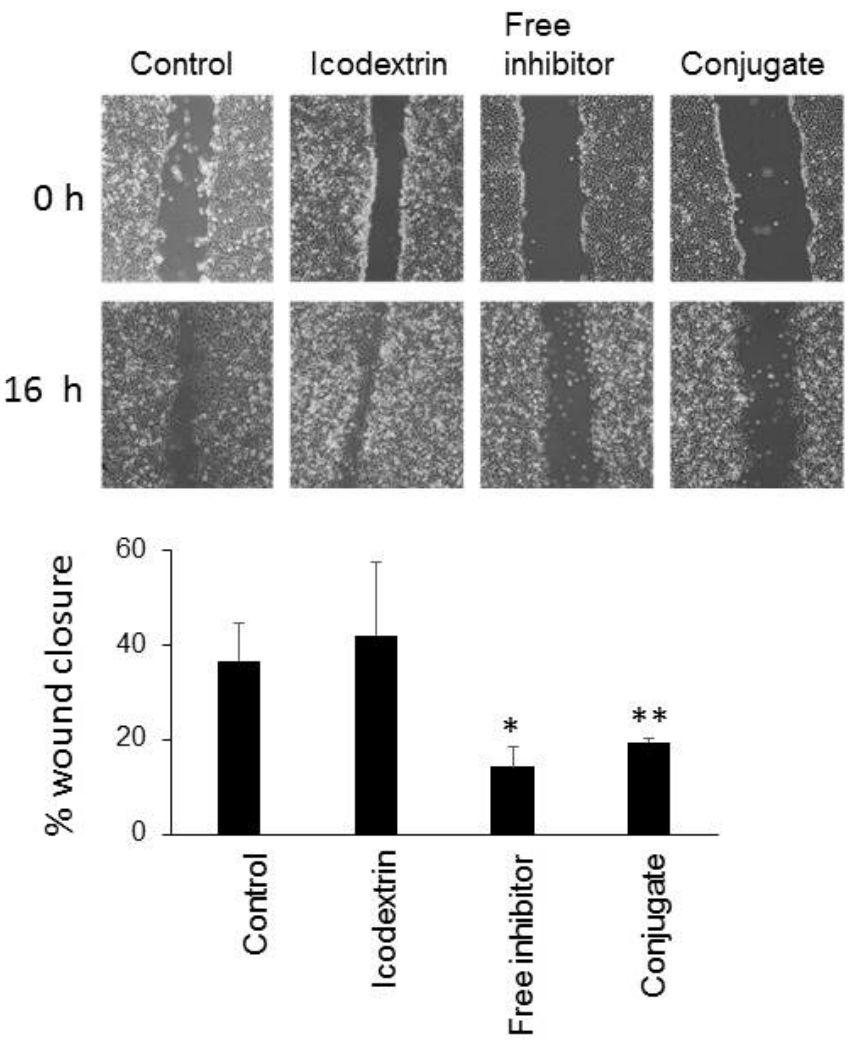

Figure 4: Comparison of autotaxin inhibition by the free inhibitor 8 or conjugate 7 on wound closure. 3E3 cells were grown to confluence, a wound was created and serum free media 
containing vehicle (DMSO), the free inhibitor $8(100 \mathrm{nM})$, or conjugate $7\left(10 \mu \mathrm{g} \mathrm{mL}^{-1}\right.$, equivalent to $1.9 \mu \mathrm{M}$ pharmacophore) was added and wound closure was measured after 16 h. The percentage wound closure was measured (mean + S.D., $n=5$ ) and was significantly different from wound closure in cells treated with vehicle where shown ${ }^{*}, \mathrm{P}<0.001 ; * *, \mathrm{P}<$ 0.005 , vs. control (paired t-test)).

\section{INTRAPERITONEAL RETENTION}

We next evaluated whether conjugation of the inhibitor to icodextrin promoted retention in the peritoneal cavity of nu/nu mice. The compounds were separately administered by the i.p. route to mice. After $24 \mathrm{~h}$ the peritoneal cavity was washed and the amount of compound present in the wash was measured. Whilst $30 \%$ of conjugate 7 was recovered from the peritoneal cavity after $24 \mathrm{~h}$, in comparison only $0.1 \%$ of the free inhibitor 8 was recovered

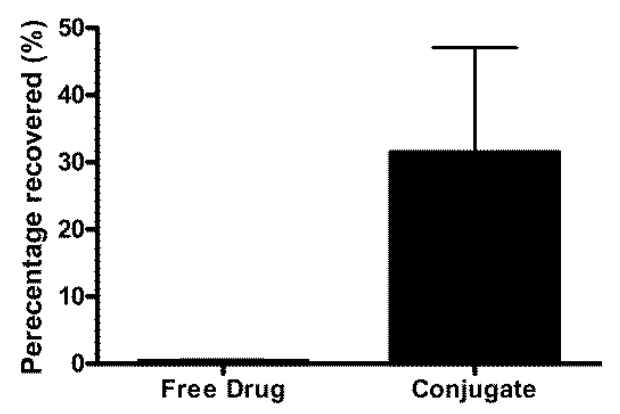

(Figure 5).

Figure 5: Peritoneal Retention of Conjugate 7 and Free Inhibitor 8. 24 h after intraperitoneal administration of the conjugate $(80 \mu \mathrm{g})$ or the free drug, the mice were sacrificed, their peritoneal cavities washed and the amount of compound recovered was determined. The 
results show the recovery expressed as a percentage of the administered compound (mean \pm S.D. of $\mathrm{n}=3$ ). For comparison, when the drug was collected immediately after administration, $40 \%$ of the drug was recovered. To confirm the specificity of the assay, no drug was detected in the peritoneal cavity of mice injected with PBS instead of the drug.

The increased levels of autotaxin and high levels of LPA that are found within the ascites fluid of patients with ovarian cancer, together with the relatively rapid clearance of low molecular mass compounds from the peritoneal cavity, ${ }^{13}$ presents a challenge to provide continual inhibition of autotaxin in the peritoneal cavity. Our study begins to address these challenges by preparing a novel conjugated equivalent from a previously described autotaxin inhibitor series. Our choice of icodextrin as the polymeric support was guided by the established history of safe and effective clinical use of icodextrin for peritoneal dialysis, and thus its pharmacokinetic properties have been well characterized. ${ }^{15}$ The relatively high molecular mass of icodextrin results in prolonged retention in the peritoneal cavity in patients and, consequently, it is highly likely that drugs that are covalently conjugated to icodextrin will be retained within the peritoneal cavity of patients, potentially leading to prolonged enzyme inhibition when compared with a free drug equivalent. Our new intraperitoneal delivery approach was shown to improve the pharmacokinetic properties of an autotaxin inhibitor, as well as increasing its solubility without substantial detrimental effects on its ability to inhibit autotaxin.

Our previous work evaluating PAMAM dendrimer conjugates of autotaxin inhibitors was not guided by knowledge of the structure of the autotaxin-drug complex, and thus resulted in an inhibitor conjugate with substantially reduced potency. ${ }^{14}$ In this present study, we have made use of the published crystal structure of the complex ${ }^{18}$ to guide our design and were able to 
successfully identify an appropriate attachment point on the inhibitor molecule. Conjugate 7 showed minimal reduction in potency compared with the free inhibitor $\mathbf{8}$ (expressed in terms of the amount of pharmacophore present). This suggests that conjugation to icodextrin had at worst a minor affect on the affinity of the pharmacophore for autotaxin. Since we anticipate administration of an icodextrin-inhibitor conjugate into the peritoneal cavity, such a minor reduction in potency is not likely to be a substantial limitation on its use.

The attachment of the pharmacophore to icodextrin also resulted in two desirable improvements in physicochemical properties. Firstly, the membrane permeability of the drug was reduced, potentially increasing the duration of its residence in the peritoneal cavity. Secondly, the solubility of the drug was also increased. One key goal of this study was to increase the retention time of the drug in the peritoneal cavity and we have established that 24 hours after intraperitoneal administration, $30 \%$ of the inhibitor conjugate was recovered from the intraperitoneal cavity. In contrast, a negligible amount of the free inhibitor was recovered. These results provide proof-of-principle that the attachment of autotaxin inhibitors to icodextrin can improve their retention time in the peritoneal cavity. That the conjugate was cleared more rapidly from mice than we anticipated, compared with the known clearance of icodextrin from human subjects, may be explained by the fact that rodents are known to have an increased amount of $\alpha$-amylase present in the peritoneal cavity compared to man, which is known to degrade icodextrin. ${ }^{24}$ Indeed, the half-life of icodextrin in rodents is known to be significantly less than in humans. ${ }^{24}$ This presents a potential issue when planning for oncology preclinical studies, since the relatively rapid clearance of icodextrin from mice makes it difficult to conduct preclinical pharmacodynamic and xenograft studies with this species. Consequently, we consider that rodents do not provide a suitable model in which the pharmacodynamic activity of inhibitor-icodextrin conjugates can be evaluated, and other model systems, or indeed human clinical trials, may be more appropriate. In contrast, clinical 
studies with icodextrin conjugates in human patients seem feasible because of the long dwell time of icodextrin in the human peritoneal cavity and the existing and safe therapeutic application of this polymer. ${ }^{15}$ Indeed, the higher molecular weight fractions of icodextrin that we have used in these studies are anticipated to be eliminated even more slowly than unfractionated icodextrin.

The strategy for intraperitoneal drug delivery that we have described herein should not be limited to autotaxin inhibitors and may be applied to other drugs where it is desirable to retain drugs in the peritoneal cavity or to alter their physicochemical properties. Intraperitoneal administration of chemotherapy is being evaluated for the treatment of ovarian cancer because it offers the potential for increased efficacy, although toxicity remains an issue with some drugs. ${ }^{25}$ Using icodextrin as a basis for drug conjugation may also be more widely applicable, for example where it is desirable to retain a drug within other body compartments. The prolonged retention of drugs in the peritoneal cavity, and potentially in other body compartments, may also allow for a relatively infrequent dosing regime to be developed.

\section{CONCLUSIONS}

In this paper we report the design and synthesis of a novel autotaxin inhibitor-icodextrin conjugate and its subsequent biological evaluation. To our knowledge, this represents the first reported use of icodextrin as a suitable polymer for the formation of covalently-bound drug conjugates. Our novel icodextrin conjugate was found to inhibit autotaxin activity using two different substrates and two different sources of autotaxin. Furthermore, the conjugate was found to reduce migration of an ovarian cell line modified to over-express autotaxin. 
Conjugation of the inhibitor to icodextrin led to an increase in solubility and a decrease in membrane permeability when compared with the free drug equivalent. Finally, when the icodextrin-inhibitor conjugate was administered to the peritoneal cavity of mice, $30 \%$ of the drug was still detected after 24 hours. These observations demonstrate that autotaxin inhibitor-icodextrin conjugates have significant potential as a new approach for the treatment of ovarian cancer.

\section{EXPERIMENTAL SECTION}

Chemistry. Reagents and solvents were obtained from commercial suppliers and were not further purified before use unless stated. Icodextrin was obtained as EXTRANEAL ${ }^{\mathrm{TM}}$ peritoneal dialysis solution $(7.5 \% \mathrm{w} / \mathrm{v}$ icodextrin in an electrolyte solution, (Baxter)). Icodextrin was isolated from Extraneal peritoneal dialysis solution following dialysis against water for 3 days, changing the solvent 3 times per day, followed by freeze-drying to remove excess water.

Solvents were removed under reduced pressure with a Büchi rotary evaporator. Any remaining solvent was removed under high vacuum. The progress of the reactions was monitored by TLC analysis, using aluminum pre-coated silica gel plates (Merck) visualised by UV irradiation at a wavelength of $254 \mathrm{~nm}$. Flash column chromatography was carried out on silica gel 60 (43-60 mesh); columns were slurry packed in the appropriate solvent/solvent mixture and samples were added as a concentrated solution or pre-absorbed onto silica. Dialysis was carried out using $20 \mathrm{kDa}$ and $8 \mathrm{kda}$ MWCO (Biotech) dialysis membrane tubing, where stated.

${ }^{1} \mathrm{H}$ and ${ }^{13} \mathrm{C}$ nuclear magnetic resonance (NMR) were measured on a Bruker DPX300 Fourier transform spectrometer, or a Jeol eclipse $400 \mathrm{MHz}$ Fourier transform spectrometer using $\mathrm{D}_{6}$ - 
DMSO, $\mathrm{CDCl}_{3}, \mathrm{D}_{2} \mathrm{O}, \mathrm{D}_{6}$-Acetone or $\mathrm{MeOD}$ solvents. Chemical shifts are quoted in ppm downfield from TMS; coupling constants $(J)$ are quoted in Hertz $(\mathrm{Hz})$. TMS was defined as 0

in ${ }^{1} \mathrm{H}$ NMR and the residual chloroform triplet as $77.10 \mathrm{ppm}$ in ${ }^{13} \mathrm{C}$ NMR. The following abbreviations were used in analysis; broad (br), singlet (s), doublet (d), triplet (t), quartet (q) and multiplet (m).

Infra-red (IR) spectra were recorded in their natural state on a Thermo Scientific GladiATR spectrometer or a Perkin Elmer spectrum 100 FT-IR spectrometer and the vibrational frequencies were recorded in $\mathrm{cm}^{-1}$.

Mass spectra were obtained from the EPSRC UK National Mass Spectrometry Facility at Swansea University, using electron spray ionisation (ESI) or atmospheric pressure chemical ionisation (APCI).

Melting points were measured on a Stuart SMP10 melting point apparatus.

The purity of all compounds was determined by elemental analysis that was performed by the elemental analysis service at London Metropolitan University, and was greater than $95 \%$.

Thermogravimetric analysis (TGA) was performed using a SDT Q 600 TA instrument, with a constant nitrogen flow of $100 \mathrm{~mL} / \mathrm{min}$, heating rate of $20{ }^{\circ} \mathrm{C} / \mathrm{min}$, heating was held stable at $100{ }^{\circ} \mathrm{C}$ for $10 \mathrm{~min}$ to remove any residual solvent. Results were obtained for greater than 10 mg per sample between 20 and $600{ }^{\circ} \mathrm{C}$.

\section{3-(4-Fluorobenzyl)thiazolidine-2,4-dione (1). ${ }^{26}$}

A solution of thiazolidine-2,4-dione $(2.93 \mathrm{~g}, 25.00 \mathrm{mmol}, 1.50$ equiv.) in DMF (anhydrous, $50 \mathrm{~mL}$ ), under $\mathrm{N}_{2}$, was cooled to $0{ }^{\circ} \mathrm{C}$ and sodium hydride ( $60 \%$ mineral oil dispersion, 0.92 g, $23.00 \mathrm{mmol}, 1.35$ equiv.) and a solution of 4-fluorobenzyl chloride $(2.04 \mathrm{~mL}, 17.00 \mathrm{mmol}$, 
1.00 equiv.) in DMF (anhydrous, $10 \mathrm{~mL}$ ) were added. The reaction mixture was allowed to warm to room temperature over $4 \mathrm{~h}$. The reaction mixture was then poured over crushed ice $(100 \mathrm{~mL})$, hexane $(50 \mathrm{~mL})$ was then added, and the product allowed to crystallise overnight at $4{ }^{\circ}$ C. 3-(4-Fluorobenzyl)thiazolidine-2,4-dione was then collected via vacuum filtration to yield $2.87 \mathrm{~g}$, (12.75 mmol, 75\%) as colourless needles; mp $78-80{ }^{\circ} \mathrm{C} .{ }^{1} \mathrm{H}$ NMR $(400 \mathrm{MHz}$, $\left.\mathrm{CDCl}_{3}\right) \delta 7.42-7.38(\mathrm{~m}, 2 \mathrm{H}) 7.03-6.99(\mathrm{~m}, 2 \mathrm{H}), 4.73(\mathrm{~s}, 2 \mathrm{H}), 3.95(\mathrm{~s}, 2 \mathrm{H})$. HRMS (APCI) $m / z$ calculated for $\mathrm{C}_{10} \mathrm{H}_{9} \mathrm{O}_{2} \mathrm{NFS}[\mathrm{M}+\mathrm{H}]^{+}:$226.0333. Found 226.0333.

\section{Methyl 4-((4-formyl-2-hydroxyphenoxy)methyl)benzoate (2).}

3,4-Dihydroxybenzaldehyde (0.15 g, $1.10 \mathrm{mmol}, 1.0$ equiv.) was dissolved in DMF (5 mL) and sodium bicarbonate ( $0.14 \mathrm{~g}, 1.65 \mathrm{mmol}, 1.5$ equiv.), methyl-4-(bromomethyl)-benzoate (0.50 g, $2.20 \mathrm{mmol}, 2.0$ equiv.) and sodium iodide ( $0.05 \mathrm{~g}, 0.33 \mathrm{mmol}, 0.3$ equiv.) were added. The reaction mixture was heated at $40{ }^{\circ} \mathrm{C}$ for $24 \mathrm{~h}$. The reaction was then quenched with $10 \%$ aqueous $\mathrm{HCl}(10 \mathrm{~mL})$, extracted with ethyl acetate $(3 \times 10 \mathrm{~mL})$, washed with brine $(3 \times 10 \mathrm{~mL})$, dried over anhydrous $\mathrm{MgSO}_{4}$ and the solvent was evaporated under reduced pressure to obtain a light brown oil. The crude product was purified by column chromatography eluting with ethyl acetate/hexane (1:4) to yield the target compound as a colourless solid (0.22 g, $0.77 \mathrm{mmol}, 70 \%)$; mp 151-153 ${ }^{\circ} \mathrm{C} .{ }^{1} \mathrm{H}$ NMR $\left(300 \mathrm{MHz},\left[\mathrm{D}_{6}\right]\right.$ DMSO) $\delta 13.02$ (br. s, 1H), $9.84(\mathrm{~s}, 1 \mathrm{H}), 7.98(\mathrm{~d}, J=8.0 \mathrm{~Hz}, 2 \mathrm{H}), 7.57$ (d, $J=8.0 \mathrm{~Hz}, 2 \mathrm{H})$, $7.54(\mathrm{~d}, J=8.2 \mathrm{~Hz}, 1 \mathrm{H}), 7.43(\mathrm{~s}, 1 \mathrm{H}), 7.26(\mathrm{~d}, J=8.2 \mathrm{~Hz}, 1 \mathrm{H}), 5.31(\mathrm{~s}, 2 \mathrm{H}), 3.85(\mathrm{~s}, 3 \mathrm{H}) .{ }^{13} \mathrm{C}$ NMR (75 MHz, [D $]$ DMSO): 191.21, 166.30, 152.23, 148.40, 145.97, 129.14, 128.91, $127.98,126.39,124.64,115.59,114.37,62.43,52.12 . \bar{v}=3672,2902,1709,1672,1606$, $1582 \mathrm{~cm}^{-1}$. HRMS (ESI) $\mathrm{m} / z$ calculated for $\mathrm{C}_{16} \mathrm{H}_{15} \mathrm{O}_{5}[\mathrm{M}+\mathrm{H}]^{+}:$287.0914. Found 287.0916. 
Elemental analysis calculated (\%) for $\mathrm{C}_{16} \mathrm{H}_{14} \mathrm{O}_{5}$ requires: $\mathrm{C} 67.13 ; \mathrm{H} \mathrm{4.93}$, found: $\mathrm{C} 67.04 ; \mathrm{H}$ 5.05 .

\section{X-ray Crystallography for 2.}

A suitable crystal was obtained by recrystallization from EtOAc/hexane. Diffraction data (26152 total reflections with $\left.R_{\text {int }}=0.038\right)$ were collected on a Bruker APEX 2 CCD diffractometer at $T=150 \mathrm{~K}$ using graphite-monochromated Mo-K $\alpha$ radiation. Crystal data: $\mathrm{C}_{16} \mathrm{H}_{14} \mathrm{O}_{5}, \mathrm{Mr}=286.27 \mathrm{~g} \mathrm{~mol}^{-1}$, orthorhombic, Pbca, $a=7.6024(6), b=16.1869(13), c=$ 21.5409(17) $\AA, \mathrm{V}=2650.8(4) \AA^{3}, Z=8, R\left[F^{2}>2 \sigma\left(F^{2}\right)\right]=0.069$ for 2900 reflections with $I>$ $2 \sigma(I), w R\left(F^{2}\right)=0.143$ for all 3422 independent data, GOF $=1.19,253$ refined parameters. CCDC 1559541 contains the supplementary crystallographic data for this paper. These data can be obtained free of charge from The Cambridge Crystallographic Data Centre via www.ccdc.cam.ac.uk/data_request/cif. Full details of the refinement and atomic positons are found in the supplementary information.

Methyl 4-((4-formyl-2-(2-(2-hydroxyethoxy)ethoxy)phenoxy)methyl)benzoate (3 ester).

Methyl 4-((4-formyl-2-hydroxyphenoxy)methyl)benzoate, 2, (0.18 g, 0.63 mmol, 1.0 equiv.) was stirred in DMF $(5 \mathrm{~mL})$ and potassium carbonate $(0.17 \mathrm{~g}, 1.25 \mathrm{mmol}, 2.0$ equiv.), potassium iodide $(0.10 \mathrm{~g}, 0.63 \mathrm{mmol}, 1.0$ equiv. $)$ and 2-(2-chloro-ethoxy)-ethanol $(0.2 \mathrm{~mL}$, $1.88 \mathrm{mmol}, 2.9$ equiv.) were added and the reaction heated to $70{ }^{\circ} \mathrm{C}$ for $18 \mathrm{~h}$. The solution was then diluted with water $(50 \mathrm{~mL})$ and extracted with ethyl acetate $(3 \times 20 \mathrm{~mL})$ and washed with water $(3 \times 20 \mathrm{~mL})$ and brine $(3 \times 20 \mathrm{~mL})$, and dried over anhydrous $\mathrm{MgSO}_{4}$. 
The solvent was then removed by evaporation under reduced pressure to yield the crude product which was purified via column chromatography (hexane/EtOAc (1:3)) to yield the target compound as a pale yellow powder $(0.14 \mathrm{~g}, 0.36 \mathrm{mmol}, 58 \%)$; mp 56-59 ${ }^{\circ} \mathrm{C} .{ }^{1} \mathrm{H}$ NMR $\left(400 \mathrm{MHz}^{\left.\mathrm{CDCl}_{3}\right)} \delta 10.46(\mathrm{~s}, 1 \mathrm{H}), 8.25(\mathrm{~d}, J=7.9 \mathrm{~Hz}, 2 \mathrm{H}), 7.57,(\mathrm{~d}, J=7.9 \mathrm{~Hz}, 2 \mathrm{H}), 7.53\right.$ (d $J=1.7 \mathrm{~Hz}, 1 \mathrm{H}), 7.43(\mathrm{dd}, J=7.9,1.7 \mathrm{~Hz}, 1 \mathrm{H}), 6.88(\mathrm{~d}, J=7.9 \mathrm{~Hz}, 1 \mathrm{H}), 4.77(\mathrm{~s}, 2 \mathrm{H})$, 3.52-3.49 (m, 2H), 3.12-3.09 (m, 2H), $3.07(\mathrm{~s}, 3 \mathrm{H}), 2.78-2.74(\mathrm{~m}, 4 \mathrm{H}) .{ }^{13} \mathrm{C}$ NMR (100 $\left.\mathrm{MHz}, \mathrm{CDCl}_{3}\right) \delta 190.97,166.84,153.67,149.36,141.33,130.63,130.08,130.00,127.08$, $126.93,112.91,111.50,72.79,70.29,69.53,68.84,61.91,52.31 . \bar{v}=3671,3504,3442,3407$, 2908, 1722, 1685, $1584 \mathrm{~cm}^{-1}$. HRMS (ESI) $\mathrm{m} / z$ calculated for $\mathrm{C}_{20} \mathrm{H}_{23} \mathrm{O}_{7}[\mathrm{M}+\mathrm{H}]^{+}: 375.1438$. Found 375.1441 .

\section{4-((4-Formyl-2-(2-(2-hydroxyethoxy)ethoxy)phenoxy)methyl)benzoic acid (3).}

Methyl 4-((4-formyl-2-(2-(2-hydroxyethoxy)ethoxy)phenoxy)methyl)benzoate (0.13 g, 0.34 mmol) was dissolved in DMSO $(1 \mathrm{~mL})$ and water $(5 \mathrm{~mL})$, and the reaction heated to $70{ }^{\circ} \mathrm{C}$ for 2 h. $1 \mathrm{M} \mathrm{NaOH}$ (aq., $1 \mathrm{~mL}$ ) was added and reaction was heated at $70{ }^{\circ} \mathrm{C}$ until the solution became clear. The reaction mixture was diluted with water $(10 \mathrm{~mL})$ and acidified to $\mathrm{pH} 2$ with $1 \mathrm{M} \mathrm{HCl}$ (aq.), and the resulting precipitate was collected by filtration to yield the target compound as a pale yellow powder $(0.12 \mathrm{~g}, 0.33 \mathrm{mmol}, 98 \%) ; \mathrm{mp} 116-119{ }^{\circ} \mathrm{C} .{ }^{1} \mathrm{H}$ NMR $\left(400 \mathrm{MHz}, \mathrm{CDCl}_{3}\right) \delta 10.47(\mathrm{~s}, 1 \mathrm{H}), 8.29(\mathrm{~d}, J=7.9 \mathrm{~Hz}, 2 \mathrm{H}), 7.60(\mathrm{~d}, J=7.9 \mathrm{~Hz}, 2 \mathrm{H}), 7.55(\mathrm{~d}$ $J=1.7 \mathrm{~Hz}, 1 \mathrm{H}), 7.46(\mathrm{dd}, J=7.9,1.7 \mathrm{~Hz}, 1 \mathrm{H}), 6.89(\mathrm{~d}, J 7.9 \mathrm{~Hz}, 1 \mathrm{H}), 4.80(\mathrm{~s}, 2 \mathrm{H}), 3.55-3.52$ (m, 2H), 3.15-3.12 (m, 2H), 2.89-2.81 (m, 4H). ${ }^{13} \mathrm{C}$ NMR (100 MHz, $\left.\mathrm{CDCl}_{3}\right) \delta$ 191.06, $170.60,153.64,149.34,142.09,130.68,130.11,129.32,127.02,126.98,112.88,111.45$, $72.79,70.27,69.54,68.78,61.88 . \bar{v}=3347,2861,1678,1584,1508 \mathrm{~cm}^{-1}$. HRMS (ESI) $\mathrm{m} / z$ calculated for $\mathrm{C}_{19} \mathrm{H}_{21} \mathrm{O}_{7}[\mathrm{M}+\mathrm{H}]^{+}:$361.1282. Found 361.1286. 


\section{(Z)-4-((4-((3-(4-fluorobenzyl)-2,4-dioxothiazolidin-5-ylidene)methyl)-2-(2-(2-}

\section{hydroxyethoxy)ethoxy)phenoxy)methyl)benzoic acid (4).}

3-(4-Fluorobenzyl)-1,3-thiazolane-2,4-dione, 1, (0.51 g, $2.25 \mathrm{mmol}, 1.0$ equiv.) was dissolved in ethanol (10 mL). Piperidine (0.22 mL, $2.25 \mathrm{mmol}, 1.0$ equiv.) and 4-((4-formyl2-(2-(2-hydroxyethoxy)ethoxy)phenoxy)methyl)benzoic acid, 3, (0.81 g, $2.25 \mathrm{mmol}, 1.0$ equiv.) were added and the solution was heated at reflux for $24 \mathrm{~h}$. The mixture was cooled to room temperature and the resulting precipitate was collected via filtration to yield the target compound as a yellow powder (1.19 g, $2.09 \mathrm{mmol}, 93 \%)$; mp $188-191{ }^{\circ} \mathrm{C} .{ }^{1} \mathrm{H}$ NMR (400 MHz, [D6]DMSO) $\delta 7.97(\mathrm{~d}, J=8.2 \mathrm{~Hz}, 2 \mathrm{H}), 7.86(\mathrm{~s}, 1 \mathrm{H}), 7.57$ (d, $J=8.2 \mathrm{~Hz}, 2 \mathrm{H}), 7.38-$ $7.33(\mathrm{~m}, 2 \mathrm{H}), 7.25(\mathrm{~s}, 1 \mathrm{H}), 7.19-7.13(\mathrm{~m}, 4 \mathrm{H}), 5.27(\mathrm{~s}, 2 \mathrm{H}), 4.79(\mathrm{~s}, 2 \mathrm{H}), 4.67$ (br. s, 1H), 4.18-4.16 (m, 2H), 3.80-3.78 (m, 2H), 3.53 (br. s, 4H). ${ }^{13} \mathrm{C}$ NMR (100 MHz, [D6]DMSO) $\delta$ 167.43 (s), 167.18 (s), $165.58(\mathrm{~s}), 161.76\left(\mathrm{~d},{ }^{1} J(\mathrm{C}, \mathrm{F})=244 \mathrm{~Hz}\right), 150.09$ (s), 148.63 (s), 141.78 (s), $133.79(\mathrm{~s}), 131.84\left(\mathrm{~d},{ }^{4} J(\mathrm{C}, \mathrm{F})=3.5 \mathrm{~Hz}\right), 130.33(\mathrm{~s}), 130.04\left(\mathrm{~d},{ }^{3} J(\mathrm{C}, \mathrm{F})=8.1 \mathrm{~Hz}\right), 129.58$ (s), 127.30 (s), 126.18 (s), 124.07 (s), 118.33 (s), 115.63 (s)*, 115.52 (d, $\left.{ }^{2} J(\mathrm{C}, \mathrm{F})=21.9 \mathrm{~Hz}\right)$ 114.27 (s), 72.69 (s), 69.42 (s), 68.86 (s), 68.46 (s), 60.37 (s), 43.93 (s). *This peak is obscured at $25^{\circ} \mathrm{C}$ but can be observed when the temperature is increased to $70{ }^{\circ} \mathrm{C} \cdot \bar{v}=3672$, 3448, 2972,2902, 1729, 1678, 1509. HRMS (ESI) $\mathrm{m} / z\left(\mathrm{MH}^{+}\right)$calcd for $\mathrm{C}_{29} \mathrm{H}_{26} \mathrm{FNO}_{8} \mathrm{~S}$ 568.1436, found 568.1430. Elemental analysis calculated (\%) for $\mathrm{C}_{29} \mathrm{H}_{26} \mathrm{FNO}_{8} \mathrm{~S}$ requires: $\mathrm{C}$ 61.37; H 4.62; N 2.47\%, found: C 61.15; H 4.73; N 2.61. 


\section{Triisopropylsilyl-(Z)-4-((4-((3-(4-fluorobenzyl)-2,4-dioxothiazolidin-5-ylidene)methyl)-}

\section{2-(2-(2-hydroxyethoxy)ethoxy)phenoxy)methyl)benzoate (5).}

$$
\text { (Z)-4-((4-((3-(4-Fluorobenzyl)-2,4-dioxothiazolidin-5-ylidene)methyl)-2-(2-(2- }
$$

hydroxyethoxy)ethoxy)phenoxy)methyl)benzoic acid, 4, (5.96 g, $10.5 \mathrm{mmol}, 1.0$ equiv.) and triisopropylsilyl chloride $(3.19 \mathrm{~mL}, 14.91 \mathrm{mmol}, 1.42$ equiv.) were stirred under nitrogen in anhydrous THF (200 mL). Triethylamine (1.61 mL, $11.55 \mathrm{mmol}, 1.1$ equiv.) was added and the reaction mixture was stirred for $15 \mathrm{~min}$ at room temperature. The resulting mixture was diluted with diethyl ether $(200 \mathrm{~mL})$ and then evaporated to yield the crude product as an oily yellow solid. The crude material was purified by column chromatography (hexane/EtOAc $(1: 1))$ to yield the target compound as a bright yellow powder $(5.78 \mathrm{~g}, 7.98 \mathrm{mmol}, 76 \%)$. Mp 107-109 ${ }^{\circ} \mathrm{C} .{ }^{1} \mathrm{H}$ NMR $\left(400 \mathrm{MHz}, \mathrm{CDCl}_{3}\right) \delta 8.07(\mathrm{~d}, J=8.3,2 \mathrm{H}), 7.80(\mathrm{~s}, 1 \mathrm{H}), 7.51(\mathrm{~d}, J=$ 8.3, 2H), $7.46-7.41(\mathrm{~m}, 2 \mathrm{H}), 7.07-7.06(\mathrm{~m}, 2 \mathrm{H}), 7.03-6.98(\mathrm{~m}, 2 \mathrm{H}), 6.92(\mathrm{~d}, J=9.0 \mathrm{~Hz}$, 1H), $5.26(\mathrm{~s}, 2 \mathrm{H}), 4.85(\mathrm{~s}, 2 \mathrm{H}), 4.25-4.22(\mathrm{~m}, 2 \mathrm{H}), 3.94(\mathrm{dd}, J=4.0,5.3 \mathrm{~Hz}, 2 \mathrm{H}), 3.74-3.69$ (m, 4H), 2.29 (br. s, 1H), 1.42 (septet, $J=7.5 \mathrm{~Hz}, 3 \mathrm{H}), 1.14$ (d, $J=7.5 \mathrm{~Hz}, 18 \mathrm{H}) .{ }^{13} \mathrm{C}$ NMR $\left(100 \mathrm{MHz}, \mathrm{CDCl}_{3}\right) \delta 167.89(\mathrm{~s}), 166.26(\mathrm{~s}), 166.03(\mathrm{~s}), 162.75\left(\mathrm{~d}, J^{1}(\mathrm{C}, \mathrm{F})=247 \mathrm{~Hz}\right), 150.66$ (s), 149.19 (s), 141.52 (s), 134.15 (s), 131.39 (s), 131.19 (d, $\left.{ }^{4} J(\mathrm{C}, \mathrm{F})=3.0 \mathrm{~Hz}\right), 131.02$ (d, $\left.{ }^{3} J(\mathrm{C}, \mathrm{F})=8.1 \mathrm{~Hz}\right), 130.67$ (s), 126.90 (s), 126.79 (s), 125.24 (s), 119.10 (s), 115.76 (d, ${ }^{2} J(\mathrm{C}, \mathrm{F})$ = 21.4 Hz), 115.27 (s), $114.14(\mathrm{~s}), 72.79$ (s), 70.36 (s), 69.57 (s), 69.05 (s), 61.92 (s), 44.59 (s), 17.99 (s), 12.18 (s). $\bar{v}=3536,2944,2868,1728,1669,1510 \mathrm{~cm}^{-1}$. HRMS (ESI) $\mathrm{m} / z$ calculated for $\mathrm{C}_{38} \mathrm{H}_{47} \mathrm{FNO}_{8} \mathrm{SSi}[\mathrm{M}+\mathrm{H}]^{+}:$724.2770. Found 724.2774. Elemental analysis calculated (\%) for $\mathrm{C}_{38} \mathrm{H}_{46} \mathrm{FNO}_{8} \mathrm{SSi}$ : C 63.05, H 6.41, N 1.93. Found: C 62.96, H 6.53, N 2.04. 


\section{Triisopropylsilyl (Z)-4-((4-((3-(4-fluorobenzyl)-2,4-dioxothiazolidin-5-ylidene)methyl)-2-}

(2-(2-(tosyloxy)ethoxy)ethoxy)phenoxy)methyl)benzoate (6).

Triisopropylsilyl (Z)-4-((4-((3-(4-fluorobenzyl)-2,4-dioxothiazolidin-5-ylidene)methyl)-2-(2(2-hydroxyethoxy)ethoxy)phenoxy)methyl)benzoate, 5, (0.40 g, $0.55 \mathrm{mmol}, 1.0$ equiv.), was stirred in dichloromethane $(12 \mathrm{~mL})$. Tosyl chloride $(0.21 \mathrm{~g}, 1.10 \mathrm{mmol}, 2.0$ equiv. $)$ and triethylamine $(0.15 \mathrm{~mL}, 1.10 \mathrm{mmol}, 2.0$ equiv. $)$ were added and the reaction mixture was stirred at room temperature for $36 \mathrm{~h}$. The reaction mixture was then evaporated to yield a yellow residue which was purified by column chromatography (50:50 ethyl acetate/petroleum ether (40-60)). Evaporation of the desired fractions afforded the target compound as a yellow crystalline solid (0.30 g, $0.34 \mathrm{mmol}, 61 \%) ; \mathrm{mp} 72-75^{\circ} \mathrm{C} .{ }^{1} \mathrm{H}$ NMR (400 MHz, [D 6 ]acetone) $\delta$ $8.09(\mathrm{~d}, J=8.2 \mathrm{~Hz}, 2 \mathrm{H}), 7.85(\mathrm{~s}, 1 \mathrm{H}), 7.77(\mathrm{~d}, J=8.2 \mathrm{~Hz}, 2 \mathrm{H}), 7.65(\mathrm{~d}, J=8.2 \mathrm{~Hz}, 2 \mathrm{H})$, 7.47-7.43 (m, 2H), $7.38(\mathrm{~d}, J=8.2 \mathrm{~Hz}, 2 \mathrm{H}), 7.24-7.21(\mathrm{~m}, 3 \mathrm{H}), 7.14-7.09(\mathrm{~m}, 2 \mathrm{H}), 5.34(\mathrm{~s}$, 2H), $4.88(\mathrm{~s}, 2 \mathrm{H}), 4.22-4.17(\mathrm{~m}, 4 \mathrm{H}), 3.80-3.77(\mathrm{~m}, 2 \mathrm{H}), 3.84-3.82(\mathrm{~m}, 2 \mathrm{H}), 2.37(\mathrm{~s}, 3 \mathrm{H})$, 1.44 (septet, $J=7.4 \mathrm{~Hz}, 3 \mathrm{H}), 1.15(\mathrm{~d}, J=7.4 \mathrm{~Hz}, 18 \mathrm{H}) .{ }^{1} \mathrm{H}$ NMR (100 MHz, [D 6 ]acetone) $\delta$ 168.15 (s), 166.59 (s), 166.39 (s), 163.26 (d, $\left.{ }^{1} J(\mathrm{C}, \mathrm{F})=247 \mathrm{~Hz}\right), 151.52$ (s), 150.22 (s), 145.66 (s), 143.43 (s), 134.31 (s), 134.2 (s), 132.99 (d, $\left.{ }^{4} J(\mathrm{C}, \mathrm{F})=2.9 \mathrm{~Hz}\right), 131.74$ (s), 131.36 $\left(\mathrm{d},{ }^{3} J(\mathrm{C}, \mathrm{F})=8.4 \mathrm{~Hz}\right), 131.03$ (s), 130.73 (s), 128.69 (s), 128.21 (s), 127.67 (s), 125.29 (s), 119.87 (s), 116.32 (s), 116.17 (d, $\left.{ }^{2} J(\mathrm{C}, \mathrm{F})=21.3 \mathrm{~Hz}\right), 115.41$ (s), 70.74 (s), 70.67 (s), 70.21 (s), 69.73 (s), 69.59 (s), 44.93 (s), 21.50 (s), 18.20 (s), 12.76 (s). $\bar{v}=2926,2867,2667,1731$, $1681,1592 \mathrm{~cm}^{-1}$. HRMS (ESI) $m / z$ calculated for $\mathrm{C}_{45} \mathrm{H}_{56} \mathrm{FN}_{2} \mathrm{O}_{10} \mathrm{~S}_{2} \mathrm{Si}\left[\mathrm{M}+\mathrm{NH}_{4}\right]^{+}: 896.3124$. Found 896.3123. Elemental analysis calculated (\%) for $\mathrm{C}_{45} \mathrm{H}_{52} \mathrm{FNO}_{8} \mathrm{SSi}$ : C 61.55, H 5.97, N 1.60. Found: C 61.44, H 5.79, N 1.71. 


\section{Synthesis of conjugate (7).}

Icodextrin (0.25 g, approx. $0.16 \mathrm{mmol}, 1.00$ equiv.) was suspended in DMAc (anhydrous, 5 $\mathrm{mL}$ ) with $\mathrm{LiCl}$ (anhydrous, $0.25 \mathrm{~g}, 5.90 \mathrm{mmol}, 3.85$ equiv.) under nitrogen, and heated to 132 ${ }^{\circ} \mathrm{C}$ with stirring until dissolved. The solution was then cooled to room temperature and sodium hydride (60\% mineral oil dispersion, $0.04 \mathrm{~g}, 1.00 \mathrm{mmol}, 0.67$ equiv.) was added and the reaction mixture stirred for $4 \mathrm{~h}$. Triisopropylsilyl-(Z)-4-((4-((3-(4-fluorobenzyl)-2,4dioxothiazolidin-5-ylidene)methyl)-2-(2-(2-

(tosyloxy)ethoxy)ethoxy)phenoxy)methyl)benzoate, $6,(0.45 \mathrm{~g}, 0.51 \mathrm{mmol}, 0.33$ equiv.) was dissolved in DMAc (anhydrous, $1 \mathrm{~mL}$ ) and added dropwise to the reaction mixture. The reaction was monitored by TLC (hexane/EtOAc (4:2)) and stirred at room temperature for 4 h. The reaction mixture was then transferred into a dialysis membrane (8000 da. MWCO) and dialyzed against methanol (1 L), with the solvent being changed 3 times per day for 3 days. The contents of the dialysis membrane were then evaporated to yield an off-white solid which was precipitated from methanol $(3 \mathrm{~mL})$ and the liquid carefully decanted, and the retained solid washed twice more with methanol and once more with dichloromethane (3 $\mathrm{mL}$ ). The remaining solid was then dried under vacuum to yield conjugate 7 directly, no additional step was required to remove the TIPS protecting group. $(0.40 \mathrm{~g}, 43 \%) . \bar{v}=3362$, $1507,1146,2361,2342,1078,1019 \mathrm{~cm}^{-1}$.

\section{Degree of substitution of IDX-conjugate.}

The degree of substitution of was determined by measuring the inherent fluorescence of the inhibitor molecule, $\left(\lambda_{\mathrm{Ex}}=360 \mathrm{~nm}, \lambda_{\mathrm{Em}}=440 \mathrm{~nm}\right)$ using a Synergy 2 microplate reader (BioTek instruments, Inc.). A calibration curve for fluorescence against concentration was 
generated by dissolving a known concentration of the molecule in DMSO and creating a dilution series with PBS (pH 7.4). Fluorescence was then measured for the test compound and compared with the standard curve and the inhibitor. The amount of inhibitor present could then be determined as a $\mathrm{mol} / \mathrm{w}$ or $\mathrm{w} / \mathrm{w}$ ratio.

\section{Biology.}

\section{Cell culture.}

Human ovarian cancer cells were maintained at $37{ }^{\circ} \mathrm{C}$ and $5 \% \mathrm{CO}_{2}$ in RPMI supplemented with $10 \%$ FCS, Penicillin/Streptomycin $\left(50 \mathrm{U} \mathrm{mL}^{-1}\right)$ and glutamine $(2 \mathrm{mM}) .3 \mathrm{E} 3$ ovarian cancer cells were previously engineered to express autotaxin ${ }^{8}$ while $3 \mathrm{~V} 3$ cells were transfected with the empty vector.

\section{Purification of autotaxin.}

3E3 cells were seeded in a T75 flask and when 50\% confluent the medium was replaced with serum free medium $(10 \mathrm{~mL})$. The next day the supernatant was collected and centrifuged (3000 rpm, $4{ }^{\circ} \mathrm{C}, 15 \mathrm{~min}$ ). The supernatant was applied to a HiTrap Con A sepharose column (GE healthcare) and recirculated for $1 \mathrm{~h}$. The column was washed with $20 \mathrm{~mL}$ tris buffered saline (TBS; $20 \mathrm{mM}$ tris, $0.5 \mathrm{M} \mathrm{NaCl}, \mathrm{pH}$ 7.4) and autotaxin eluted with $2 \mathrm{~mL} \alpha$ methylmannoside $(0.5 \mathrm{M})$ in TBS overnight. The eluate was dialysed against TBS and used as the source of autotaxin for the bis $p$ NPP assay.

\section{FS-3 assay.}

FS-3 is a fluorescence-quenched analogue of lysophosphatidylcholine (Echelon Biosciences, Inc. Salt Lake City, UT). Compounds to be tested were prepared as stock solutions in DMSO 
$(10 \mu \mathrm{M})$. The drug $(10 \mu \mathrm{L})$ was incubated with $80 \mu \mathrm{L}$ reaction buffer containing autotaxin for 10 min at $37^{\circ} \mathrm{C}$ before addition of $10 \mu \mathrm{L}$ FS-3 substrate. The rate of increase in fluorescence was measured at $37^{\circ} \mathrm{C}$ every minute for 30 min using a Synergy 2 multi-mode microplate reader (BioTek instruments, Inc.) $(\lambda=528 \mathrm{~nm})$. Data was analysed using GraphPad Prism software.

\section{Bis-pNPP Assay.}

Inhibition of autotaxin activity was measured using the autotaxin substrate bis-paranitrophenylphosphate (bis- $p$ NPP). $20 \mu \mathrm{L} 5 \mathrm{X}$ reaction buffer $(250 \mathrm{mM}$ Tris $\mathrm{HCl}, 25 \mathrm{mM} \mathrm{KCl}$, $\left.5 \mathrm{mM} \mathrm{CaCl}_{2}, 5 \mathrm{mM} \mathrm{MgCl} 2.6 \mathrm{H}_{2} \mathrm{O}, \mathrm{NaCl} 700 \mathrm{mM}, \mathrm{pH} 7.8\right), 10 \mu \mathrm{L}$ bis- $p \mathrm{NPP}(1 \mathrm{mM}), 20 \mu \mathrm{L}$ inhibitor was added to each well of an opaque 96 well plate, followed by the addition of 50 $\mu \mathrm{L}$ autotaxin purified from $3 \mathrm{E} 3$ cells. After incubation $\left(37^{\circ} \mathrm{C}, 4 \mathrm{~h}\right) \mathrm{A}_{405}$ was determined and data was analysed using graph pad prism software to fit a 4 parameter Hill equation.

\section{Wound healing assay.}

3V5 and 3E3 cells $(100,000$ cells/ml) were plated in 6 well plates in RPMI supplemented with FCS (10\%). When the cells had reached confluence the medium was removed and a plastic pipette tip used to produce a clean wound area. The wells were washed with PBS and serum free medium added containing lysophosphatidyl choline $(0.5 \mu \mathrm{M})$, and either the inhibitor or solvent. The cells were viewed by phase contrast microscopy immediately after wounding. After $16 \mathrm{~h}$ the cells were stained and fixed with methylene blue (200 $\mu \mathrm{L}$, Sigma M9140; $0.5 \% \mathrm{w} / \mathrm{v}$ in $\left.50 \% \mathrm{H}_{2} \mathrm{O}, 50 \% \mathrm{EtOH}\right)$. Images of the wound were captured by light microscopy and wound closure measured $(\mu \mathrm{m})$ using image J software. The area of a section of the wound pre- and post-migration was then measured and the percentage wound closure was calculated as described. ${ }^{14}$ 
PAMPA.

The free inhibitor $8(1 \mathrm{mM})$ and conjugate $7\left(10 \mathrm{mg} \mathrm{mL}^{-1}\right)$ were prepared as stock solutions in DMSO, and icodextrin $\left(10 \mathrm{mg} \mathrm{mL}^{-1}\right)$ in water. Membranes were wetted with dodecane containing PC (5 mg mL $\left.\mathrm{mL}^{-1}\right) 5 \mu \mathrm{L}$ per well. Immediately after wetting $150 \mu \mathrm{L}$ of either furosemide $(10 \mu \mathrm{M}$, poorly permeable), propranolol $(10 \mu \mathrm{M}$, highly permeable), free inhibitor $(10 \mu \mathrm{M})$, or conjugate $\left(100 \mu \mathrm{g} \mathrm{mL}^{-1}\right)$, was added to the appropriate donor well, and the donor compartment was placed in the acceptor plate, each acceptor well containing $300 \mu \mathrm{L}$ of PBS (2\% DMSO). The plates were incubated in a moist environment at room temperature for $48 \mathrm{~h}$. The amount of compound present in the donor and acceptor compartments was measured by UV/VIS or fluorescence spectroscopy.

\section{Caco-2 permeability assay.}

Caco-2 100,000 cell $/ \mathrm{cm}^{2}$ were plated in transwells (surface area $0.33 \mathrm{~cm}^{2}, 0.4 \mu \mathrm{m}$ pore size, Greiner Bio-One) in 24-well plates containing $500 \mu \mathrm{L}$ medium per well and cultured for 28 days changing the medium every three days. Medium was changed to serum free medium in both the apical and basolateral side. After incubation with serum free medium for $3 \mathrm{~h}$, washing twice with hepes-buffered sterile saline (HBSS), $500 \mu \mathrm{L}$ of HBSS was placed in the basolateral side and $500 \mu \mathrm{L}$ of HBSS containing either the free inhibitor $\left(10 \mu \mathrm{g} \mathrm{mL}^{-1}\right)$ or conjugate $\left(100 \mu \mathrm{g} \mathrm{mL}^{-1}\right)$ was added to the apical side. The cells were incubated for $2 \mathrm{~h}$, after which the supernatant was collected from both the apical and basolateral side. The concentration of the analysed compounds was measured by fluorescence as described above.

\section{In vivo experiments.}


Animal experiments were performed under the guidelines and were approved by the animal welfare commission of Keele University. Female NCR Nu/Nu mice weighing between 5 and 7 weeks were used and allowed to acclimatise for 1 week after arrival. Before use, the icodextrin drug conjugate was sterilised by suspending a known amount in $70 \%$ ethanol followed by freeze-drying (Edwards Modulo), for $4 \mathrm{~h}$ to remove all traces of solvent. The residue was then dissolved in sterile PBS and diluted to concentrations of $0.22 \mathrm{mg} \mathrm{mL}^{-1}, 0.1$ $\mathrm{mg} \mathrm{mL} \mathrm{m}^{-1}$ and $0.03 \mathrm{mg} \mathrm{mL} \mathrm{m}^{-1}$. Mice were injected with $0.4 \mathrm{~mL}$ of drug into the peritoneal cavity with a 26G syringe in the lower left quadrant. 3 mice per time point were euthanized by cervical dislocation at $1 \mathrm{~min}, 30 \mathrm{~min}, 60 \mathrm{~min}, 3 \mathrm{~h}, 6 \mathrm{~h}$ and $24 \mathrm{~h}$ after injection. $0.4 \mathrm{~mL}$ PBS was used as a control for background fluorescence (see below) and mice in this group were euthanized after 1 min by cervical dislocation. Ventral skin was removed and $0.5 \mathrm{~mL}$ sterile PBS was added to the peritoneal cavity, the wash was collected after gentle massage with the blunt end of forceps. The washes were immediately centrifuged (6000 rpm, $10 \mathrm{~min}$ ) and the supernatant was transferred to a new microcentrifuge tube. The volume collected was measured and the fluorescence, $\left(\lambda_{\mathrm{Ex} .}=360 \mathrm{~nm}, \lambda_{\mathrm{Em} .}=440 \mathrm{~nm}\right)$ of $100 \mu \mathrm{L}$ of each wash was measured using a Synergy 2 multimode microplate reader. The amount of drug present was calculated from the standard curve to determine drug concentration and from the sample volume. The data was analysed using GraphPad software to fit an exponential decay to calculate the half-life. The drug recovery by peritoneal lavage was estimated by comparison of the mass of drug injected with the mass recovered 1 minute after injection. 


\section{ACKNOWLEDGEMENTS}

This research was supported by MRC (grant G1100184). The authors would like to acknowledge the Universities of Keele, Loughborough and Nottingham Trent, and Charnwood Molecular Ltd., for facilities and financial support of this research. We would also like to acknowledge the support of the EPSRC UK National Mass Spectrometry Facility at Swansea University.

\section{ABBREVIATIONS USED}

bis- $p$ NPP, bis-paranitrophenyl phosphate; DMAc, $N, N$-dimethylacetamide; FS-3, Flurogenic substrate 3; FCS, Fetal calf serum; LPC, lysophosphatidyl choline; LPA, lysophosphatidic acid; PAMAM, polyamidoamine; TGA, Thermogravimetric analysis.

\section{ASSOCIATED CONTENT}

\section{Supporting Information}

The Supporting Information is available free of charge on the ACS Publications website at DOI:

1H and 13C NMR spectra for compounds 1-6 (PDF) and molecular-formula strings (CSV). 


\section{REFERENCES}

1. (a) Stracke, M. L.; Krutzsch, H. C.; Unsworth, E. J.; Arestad, A.; Cioce, V.; Schiffmann, E.; Liotta, L. A. Identification, purification, and partial sequence-analysis of autotaxin, a novel motility-stimulating protien. J. Biol. Chem. 1992, 267, 2524-2529; (b) Clair, T.; Lee, H. Y.; Liotta, L. A.; Stracke, M. L. Autotaxin is an exoenzyme possessing 5'nucleotide phosphodiesterase/ATP pyrophosphatase and ATPase activities. J. Biol. Chem. 1997, 272, 996-1001.

2. (a) Tokumura, A.; Majima, E.; Kariya, Y.; Tominaga, K.; Kogure, K.; Yasuda, K.; Fukuzawa, K. Identification of human plasma lysophospholipase D, a lysophosphatidic acidproducing enzyme, as autotaxin, a multifunctional phosphodiesterase. J. Biol. Chem. 2002, 277, 39436-39442; (b) Umezu-Goto, M.; Kishi, Y.; Taira, A.; Hama, K.; Dohmae, N.; Takio, K.; Yamori, T.; Mills, G. B.; Inoue, K.; Aoki, J.; Arai, H. Autotaxin has lysophospholipase D activity leading to tumor cell growth and motility by lysophosphatidic acid production. $J$. Cell Biol. 2002, 158, 227-233.

3. (a) Anliker, B.; Chun, J. Lysophospholipid G protein-coupled receptors. J. Biol. Chem. 2004, 279, 20555-20558; (b) Hurst, J. H.; Mendpara, N.; Hooks, S. B. Regulator of Gprotein signalling expression and function in ovarian cancer cell lines. Cell Mol. Biol. Lett. 2009, 14, 153-174.

4. $\quad$ Fang, X. J.; Schummer, M.; Mao, M. L.; Yu, S. X.; Tabassam, F. H.; Swaby, R.; Hasegawa, Y.; Tanyi, J. L.; LaPushin, R.; Eder, A.; Jaffe, R.; Erickson, J.; Mills, G. B. Lysophosphatidic acid is a bioactive mediator in ovarian cancer. Biochim. Biophys. Acta Mol. Cell Biol. Lipids 2002, 1582 (1-3), 257-264.

5. Xu, Y.; Gaudette, D. C.; Boynton, J. D.; Frankel, A.; Fang, X. J.; Sharma, A.; Hurteau, J.; Casey, G.; Goodbody, A.; Mellors, A.; Holub, B. J.; Mills, G. B. 
Characterization of an ovarian cancer activating factor in ascites from ovarian cancer patients. Clin. Cancer Res. 1995, 1, 1223-1232.

6. Tokumura, A.; Kume, T.; Fukuzawa, K.; Tahara, M.; Tasaka, K.; Aoki, J.; Arai, H.; Yasuda, K.; Kanzaki, H. Peritoneal fluids from patients with certain gynecologic tumor contain elevated levels of bioactive lysophospholipase D activity. Life Sci. 2007, 80, 16411649.

7. Jazaeri, A. A.; Avvtrey, C. S.; Chandramouli, G. V. R.; Chuang, Y. E.; Khan, J.; Sotiriou, C.; Aprelikova, O.; Yee, C. J.; Zorn, K. K.; Birrer, M. J.; Barrett, J. C.; Boyd, J. Gene expression profiles associated with response to chemotherapy in epithelial ovarian cancers. Clin. Cancer Res. 2005, 11, 6300-6310.

8. Vidot, S.; Witham, J.; Agarwal, R.; Greenhough, S.; Bamrah, H. S.; Tigyi, G. J.; Kaye, S. B.; Richardson, A. Autotaxin delays apoptosis induced by carboplatin in ovarian cancer cells. Cellular Signalling 2010, 22, 926-935.

9. (a) Huang, R. Y.; Wang, S. M.; Hsieh, C. Y.; Wu, J. C. Lysophosphatidic acid induces ovarian cancer cell dispersal by activating Fyn kinase associated with p120-catenin. Int. J. Cancer 2008, 123, 801-809; (b) Gil, O. D.; Lee, C.; Ariztia, E. V.; Wang, F. Q.; Smith, P. J.; Hope, J. M.; Fishman, D. A. Lysophosphatidic acid (LPA) promotes E-cadherin ectodomain shedding and OVCA429 cell invasion in an uPA-dependent manner. Gynecol. Oncol. 2008, 108, 361-369; (c) Do, T. V.; Symowicz, J. C.; Berman, D. M.; Liotta, L. A.; Petricoin, E. F., 3rd; Stack, M. S.; Fishman, D. A. Lysophosphatidic acid down-regulates stress fibers and up-regulates pro-matrix metalloproteinase- 2 activation in ovarian cancer cells. Mol. Cancer Res. 2007, 5, 121-131; (d) Kim, E. K.; Park, J. M.; Lim, S.; Choi, J. W.; Kim, H. S.; Seok, H.; Seo, J. K.; Oh, K.; Lee, D. S.; Kim, K. T.; Ryu, S. H.; Suh, P. G. Activation of AMP-activated protein kinase is essential for lysophosphatidic acid-induced cell migration in ovarian cancer cells. J. Biol. Chem. 2011, 286, 24036-24045; (e) Bian, D.; 
Mahanivong, C.; Yu, J.; Frisch, S. M.; Pan, Z. K.; Ye, R. D.; Huang, S. The G12/13-RhoA signaling pathway contributes to efficient lysophosphatidic acid-stimulated cell migration. Oncogene 2006, 25, 2234-2244; (f) Bian, D.; Su, S.; Mahanivong, C.; Cheng, R. K.; Han, Q.; Pan, Z. K.; Sun, P.; Huang, S. Lysophosphatidic acid stimulates ovarian cancer cell migration via a Ras-MEK kinase 1 pathway. Cancer Res. 2004, 64, 4209-4217; (g) Fishman, D. A.; Liu, Y.; Ellerbroek, S. M.; Stack, M. S. Lysophosphatidic acid promotes matrix metalloproteinase (MMP) activation and MMP-dependent invasion in ovarian cancer clls. Cancer Res. 2001, 61, 3194-3199; (h) Wang, F. Q.; Smicun, Y.; Calluzzo, N.; Fishman, D. A. Inhibition of matrilysin expression by antisense or RNA interference decreases lysophosphatidic acid-induced epithelial ovarian cancer invasion. Mol. Cancer Res. 2006, 4, 831-841; (i) Sengupta, S.; Kim, K. S.; Berk, M. P.; Oates, R.; Escobar, P.; Belinson, J.; Li, W.; Lindner, D. J.; Williams, B.; Xu, Y. Lysophosphatidic acid downregulates tissue inhibitor of metalloproteinases, which are negatively involved in lysophosphatidic acidinduced cell invasion. Oncogene 2007, 26, 2894-2901.

10. Vidot, S.; Witham, J.; Agarwal, R.; Greenhough, S.; Bamrah, H. S.; Tigyi, G. J.; Kaye, S. B.; Richardson, A. Autotaxin delays apoptosis induced by carboplatin in ovarian cancer cells. Cell. Signal. 2010, 22, 926-935.

11. Samadi, N.; Gaetano, C.; Goping, I. S.; Brindley, D. N. Autotaxin protects MCF-7 breast cancer and MDA-MB-435 melanoma cells against taxol-induced apoptosis. Oncogene 2009, 28, 1028-1039.

12 (a) Castagna, D; Budd, D.C.; Macdonald, S.J.F.; Jamieson, C.; Watson, A.J.B. Development of autotaxin inhibitors: an overview of the patent and primary literature. J. Med. Chem, 2016, 59, 5604-5621. (b) Nikolaou, A.; Kokotou, M.G.; Limnios, D.; Psarra, A.; \& Kokotos, G. Autotaxin inhibitors: a patent review (2012-2016). Expert Opin. Ther. Pat. 2017, 27, 815-829 
13. (a) Lukas, G.; Brindle, S. D.; Greengar. P. Route of absorbption of intraperitoneally administered compounds. J. Pharm. Exp. Ther. 1971, 178, 562-566; (b) Dedrick, R. L.; Flessner, M. F. Pharmacokinetic problems in peritoneal dug administration: tissue penetration and surface exposure. J. Natl. Cancer Inst. 1997, 89, 480-487.

14. Fisher, N.; Hilton-Bolt, T.; Edwards, M. G.; Haxton, K. J.; McKenzie, M.; Allin, S. M.; Richardson, A. dendrimer conjugate of 4-(tetradecanoylamino)benzyl phosphonic acid (S32826) as an autotaxin Inhibitor. ACS Med. Chem. Lett. 2014, 5, 34-39.

15. Moberly, J. B.; Mujais, S.; Gehr, T.; Hamburger, R.; Sprague, S.; Kucharski, A.; Reynolds, R.; Ogrinc, F.; Martis, L. Wolfson, M., Pharmacokinetics of icodextrin in peritoneal dialysis patients. Kidney Int. Suppl. 2002, (81), S23-S33.

16. (a) Engler, H.; Machemer, T. R.; Schluep, T.; Wen, S. F.; Quijano, E.; Wills, K. N.; Harper, A. E.; Maneval, D. C.; Conroy, S. E. Development of a formulation that enhances gene expression and efficacy following intraperitoneal administration in rabbits and mice. Mol. Ther. 2003, 7, 558-564; (b) Kerr, D. J.; Young, A. M.; Neoptolemos, J. P.; Sherman, M.; Van-Geene, P.; Stanley, A.; Ferry, D.; Dobbie, J. W.; Vincke, B.; Gilbert, J.; el Eini, D.; Dombros, N.; Fountzilas, G. Prolonged intraperitoneal infusion of 5-fluorouracil using a novel carrier solution. Br. J. Cancer 1996, 74, 2032-2035; (c) McArdle, C. S.; Kerr, D. J.; O'Gorman, P.; Wotherspoon, H. A.; Warren, H.; Watson, D.; Vinke, B. J.; Dobbie, J. W.; el Eini, D. I. Pharmacokinetic study of 5-fluorouracil in a novel dialysate solution: a long-term intraperitoneal treatment approach for advanced colorectal carcinoma. Br. J. Cancer 1994, $70,762-766$.

17. Albers, H. M.; van Meeteren, L. A.; Egan, D. A.; van Tilburg, E. W.; Moolenaar, W. H.; Ovaa, H. Discovery and optimization of boronic acid based inhibitors of autotaxin. $J$. Med. Chem. 2010, 53, 4958-4967 
18. Hausmann, J.; Kamtekar, S.; Christodoulou, E.; Day, J. E.; Wu, T.; Fulkerson, Z.; Albers, H. M.; van Meeteren, L. A.; Houben, A. J. S.; van Zeijl, L.; Jansen, S.; Andries, M.; Hall, T.; Pegg, L. E.; Benson, T. E.; Kasiem, M.; Harlos, K.; Kooi, C. W. V.; Smyth, S. S.; Ovaa, H.; Bollen, M.; Morris, A. J.; Moolenaar, W. H.; Perrakis, A. Structural basis of substrate discrimination and integrin binding by autotaxin. Nat. Struct. Mol. Biol. 2011, 18, 198-204.

19. Plourde, G. L.; Spaetzel, R. R. Regioselective protection of the 4-hydroxyl of 3,4dihydroxy-benzaldehyde. Molecules 2002, 7, 697-705.

20. Zhang, C.; Liu, R.; Xiang, J.; Kang, H.; Liu, Z.; Huang, Y. Dissolution mechanism of cellulose in $\mathrm{N}, \mathrm{N}$-dimethylacetamide/lithium chloride: revisiting through molecular interactions. J. Phys. Chem. B 2014, 118, 9507-9514.

21. Liu, C.; Baumann, H. Exclusive and complete introduction of amino groups and their $\mathrm{N}$-sulfo and $\mathrm{N}$-carboxymethyl groups into the 6-position of cellulose without the use of protecting groups. Carbohydr. Res. 2002, 337, 1297-1307.

22. Ferguson, C. G.; Bigman, C. S.; Richardson, R. D.; van Meeteren, L. A.; Moolenaar, W. H.; Prestwich, G. D. Fluorogenic phospholipid substrate to detect lysophospholipase D/autotaxin activity. Org. Lett. 2006, 8, 2023-2026.

23 van Meeteren, L. A.; Ruurs, P.; Christodoulou, E.; Goding, J. W.; Takakusa, H.; Kikuchi, K.; Perrakis, A.; Nagano, T.; Moolenaar, W. H. Inhibition of autotaxin by lysophosphatidic acid and sphingosine 1-phosphate. J. Biol. Chem. 2005, 280, 21155-21161.

24. de Waart, D. R.; Zweers, M. M.; Struijk, D. G.; Krediet, R. T. Icodextrin degradation products in spent dialysate of CAPD patients and the rat, and its relation with dialysate osmolality. Perit. Dial. Int. 2001, 21, 269-274. 
25. Kwa, M.; Jandial, D. Modulation of intraperitoneal (IP) chemotherapy in ovarian cancer. Translational Cancer Research 2015, 4, 60-69.

26. Nitsche, C.; Schreier, V.N.; Behnam, M.A.M; Kumar, A.; Bartenschlager, R.; Klein, C.D. Thiazolidinone-peptide hybrids as dengue virus protease inhibitors with antiviral activity in cell culture. $J$. Med. Chem., 2013, 56, 8389-8403. 


\section{TOC Graphic}

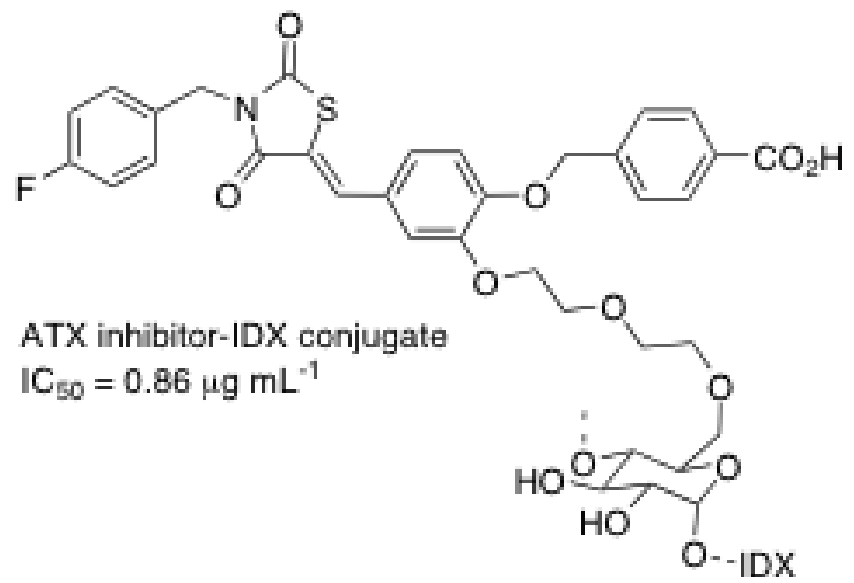

